\title{
Internalization of Islamic Values in Developing Students' Actual Morals
}

\author{
Syahraini Tambak ${ }^{1 *}$, Hamzah$^{2}$, Desi Sukenti ${ }^{3}$, Mashitah Sabdin ${ }^{4}$ \\ 1,2 Department of Islamic Religion Education, Universitas Islam Riau, Pekanbaru, Indoensia \\ ${ }^{3}$ Department of Indonesian Language and Literature, Universitas Islam Riau, Pekanbaru, Indonesia \\ ${ }^{4}$ Department of Management and Humanities, Universiti Teknologi PETRONAS, Perak Darul Ridzuan, Malaysia \\ *e-mail: syahraini tambak@fis.uir.ac.id
}

\begin{abstract}
This study aims to explore the efforts of madrasah teachers to internalize Islamic values in developing students' actual morals. Using case study research by conducting in-depth interviews with 8 madrasah tsanawiyah teachers and analyzing them with data cleaning, transcripts, coding and categorization, and interpretation. This research resulted in: First, duha sunnah and fardhu prayer in congregation, and get used to respect the teacher, to manage the syahwiya power of students, resulting in "iffah" which gave birth to the morals of jud, syakha', qana'ah, amanah, zuhud, rahmah, hilm, and al-afwu. Second, get used to dzikrullah, and accustom shiyam sunnah, to curb the hammiya power of students, resulting syaja'ah, 'adalah, insan, insyaf, rahmah, and hilm. Third, get used to muhadharah activities, and Islamic integrative learning, to educate students' powers of mufakkara, thus giving birth to wisdom and fathanah behavior. It can be concluded that the internalization of Islamic values in developing students' actual morals is duha sunnah and fardhu prayer in congregation, get used to respect the teacher, get used to dzikrullah, accustom shiyam sunnah, muhadharah activity, and Islamic integrative learning, to curb the spiritual power of shahwiya, manage power of hammiya, and educating students powers of mufakkara, thus giving birth to the behavior of' iffah, jud, syakha', qana'ah, amanah, zuhud, rahmah, hilm, al-afwu, syaja'ah, 'adalah, insan, insyaf, mujahadah, sabr, wisdom, and fathanah. The results of this study have implications for the theory of "Islamic moral development" which can be applied to all madrasah education in Indonesia and the Islamic world.
\end{abstract}

Keywords: Moral, Islamic Values, Internalization

\section{Introduction}

Actual moral development is very popular in madrasa education because it is the key to success in the student's life later in life. Humans who have actual morals are the basis for success in the profession at hand (Darnell et al., 2019; Tomasello, 2018). The body of literature shows that the actual morals of students are all forms of virtue that are implemented from the attributes of Allah in everyday life and have an impact on one's success in the future (Safitri et al., 2019; S. Tambak, Humairoh, et al., 2020). Morals are a person's good behavior which becomes the basis for acting that leads humans to success (Luttrell et al., 2019; Thambu et al., 2021). The moral is a set of values about various kinds of behavior that must be obeyed. Morals are norms and institutions that regulate individual behavior in social groups and society (Baker et al., 2021; Khaironi, 2017; Yusoff et al., 2021). Morality is an aspect of personality that is needed by a person in interacting with social, fair, and balanced life (Ibam et al., 2018; Setiawati et al., 2019).

These various studies lead to the development of student morals with various solutions offered, but this problem still occurs in students in madrasas, including at Madrasah Tsanawiyah Negeri 3 Kota Pekanbaru, Indonesia. Symptoms were found where there were some students in this madrasah, who were not good at implementing good behavior at school, did not respect teachers, including parents, and did not respect friends, and also did not work hard in learning. In fact, this does not happen to students, because teachers in madrasas have always provided direction, teaching and guidance to apply actual morals in every action both in madrasas and in society. So, this problem is very urgent to be repaired

\footnotetext{
${ }^{*}$ Corresponding author.
}

Received December 09, 2020; Accepted April 10, 2021 Available online December 25, 2021

This is an open access article under the CC BY-SA license. Copyright $(\odot 2021$ by Author. Published by Universitas Pendidikan Ganesha 
academically and non-academically so that students have good Islamic behavior. If the solution is late, it will have an impact on the emergence of bad generations in the future (lannuccilli et al., 2021; Safitri et al., 2019; Salistina, 2015). Because the progress of the civilization of the nation and society, one of which is measured based on the good moral ownership of each individual in life (Ahmed et al., 2019; Ru'iya, 2019).

Previous research examined Islamic behavior by incorporating Islamic teachings in developing it in communication and life as a model for children's spiritual education (Ganjvar, 2019). Research in East Anglia, sees that How moral decision making occurs, matures over time and deals with behavior is complex (Garrigan et al., 2018). Thus, it is necessary to develop a complete picture of moral decision making, moral development and moral behavior. Previous research examines the Islamic background of Thai Muslim youth in three southern border provinces of Thailand in terms of upbringing, studying, carrying out religious duties, and participating in activities (Laeheem, 2020). Morals are the main problem in every behavior that is developed. The research which investigated moral identity from a crosscultural perspective by comparing Western (Canadian) and Eastern (Chinese) cultures in three different contexts: family, school and community/society (Jia et al., 2019). Research in Semarang, Indonesia which develops morals in learning with various approaches (Mu'awanah, 2018). The morals of the nation's generation need improvement so that a moral education design is needed for personal and community Islamization (Ayu \& Junaidah, 2018; Basuki \& Febriansyah, 2020; Maulida, 2017; Zainuddin, 2019).

So, to solve this student moral problem requires the efforts of madrasa teachers, in addition to what has been researched by previous researchers, by internalizing Islamic values in developing the actual morals of students in madrasas. This study examines the efforts of madrasah teachers to internalize Islamic values in developing actual morals of students of Madrasah Tsanawiyah Negeri 3 Pekanbaru. This research is a new research that has never been researched by other researchers at MTs Negeri 3 Pekanbaru madrasah education. This research focuses on; internalization of Islamic values in curbing the syahwiya spirit of students so as to produce actual morals; internalization of Islamic values in managing the hammiya power of students so as to produce actual morals; and internalization of Islamic values in educating students' mental powers of mufakkara so as to produce actual morals. Thus, a model of internalization of Islamic values will be found in developing the actual morals of madrasah students.

\section{Method}

This type of research is qualitative using a case study approach, which aims to explore the efforts of teachers to internalize Islamic values in developing students' actual morals based on a collection of various field data from madrasah teachers (Burke Johnson, 2014). This research was conducted at Madrasah Tsanawiyah Negeri 3 Pekanbaru, Indonesia, for 1 years, and involved 8 madrasah teachers consisting of 3 male and 5 female. Data collection was carried out using in-depth interview techniques. Each madrasah teacher participated in three series of interviews with researchers. Each interview lasts up to 2-3 hours. This series of three interviews, focuses on exploring detailed experiences, and the latter focuses on "reflection on meaning (McGrath et al., 2019). The first interview used the life narrative method and asked the madrasa teacher to reflect on "the internalization of Islamic values in shaping the Islamic behavior of their students?" The second interview was to explore the experiences of teachers and how they actually applied the internalization of Islamic values in developing students' actual morals in learning in madrasas. The third interview explores how the method of internalizing Islamic values is used by teachers in developing the actual character of students in the madrasah environment.

Data analysis was carried out through several stages, namely data cleaning, transcripts, coding and categorization, and interpretation (Netolicky \& Barnes, 2018). Each evening following data collection, my team members and I discussed the information we found, identifying what was relevant and what was not for research purposes. After the data is cleaned, we make verbatim transcriptions and analyze them into good and correct 
Indonesian. I coded the transcripts, grouped them into themes, and compared them across phenomena. The themes that most often arise from the three problems include; (a) internalizing Islamic values in educating the mental strength of mufakkara; (b) internalization of Islamic values in suppressing the spiritual strength of the hammiya so as to create the actual morals of the students; (c) internalizing Islamic values in managing the spiritual strength of the syahwiya to give birth to students' actual morals. Under each of these themes, several sub-themes were identified; some of them differ from case to case. With these steps, I succeeded in producing theoretical prepositions from the data on the internalization of Islamic values in developing the actual morals of students in madrasas.

\section{Result and Discussion}

\section{Results}

The formation of Islamic behavior of students begins by focusing on the power of the soul in humans, namely the power of syahwiya or commonly called lust. Worldly lust is a soul that always puts forward materialistic desires and worships a hedonistic world without limits. The power of syahwiya must be suppressed in life activities by; habituation of duha sunnah and fardhu prayers in congregation, amd get used to respect the teacher. Both of these methods are able to suppress the soul's power of shahwiya, which in turn give birth to 'iffah' virtuous attitudes and deeds. Strengthening the virtue of 'iffah with these three methods produces jud, syaka', amanah, 'afwu, zuhud, rahmah, and hilm. It is these virtues that make students righteous individuals. The process of Islamic internalization to develop student morals at Madrasah Tsanawiyah Negeri 3 Pekanbaru is carried out through habituation of dhuha prayer and fardhu prayer in congregation. The implementation of the duha and fardhu prayer program is related to the mission of the madrasa which is to make madrasas superior in the moral development of students. All teachers in madrassas feel that the application of the habit of sunnah and fardhu prayer is very important to shape students' morals in everyday life. The practice of sunnah prayer in madrasas is intended to suppress the power of syahwiya or worldly desires. This is done so that students are aware that with the Sunnah prayer life will be disciplined, focused and meaningful.

Every morning, student activities begin with the duha sunnah prayer. This sunnah prayer is mandatory for all students without exception. This prayer is also performed in the mosque together, but not in congregation. Even so, the teachers continued to lead in front like a priest. The implementation of the Dhuha prayer which starts learning activities in the morning is intended so that students have a sincere, clean, obedient, religious and highly motivated spirit to participate in learning activities. Regarding the dhuha prayer program, there are several characters that are inherent and formed in students in madrasas. "Especially in terms of Duha prayer, it can build creative and disciplined character. Prayers that are done properly and regularly certainly teach and familiarize the practitioner to have thuma'ninah and istiqomah habits. Habits like this are believed to be able to restore, calm, and silence the mind so that not only is it ready to return to activities with full force, but also allows creative thoughts to be born,"(1) said a teacher. Morals that are developed through the implementation of Duha prayer according to one teacher are:

"Moral love for Allah. To realize this character, it is necessary to have a special approach in which students are encouraged to introduce sunnah worship in addition to compulsory worship, one of which is by emphasizing students to always pray dhuha every day before teaching and learning activities begin. And also understand students that they do whatever they want because of Allah. The next morals are self-confidence and responsibility. The approach is taken as a form of student self-confidence by teaching students to lead prayers in front of their friends. By training students to lead prayers in front of them, thereby teaching children to appear in front of the crowd in the hope that the students will bring out the character of courage and confidence"(3).

Carrying out the fardhu prayer in congregation is a routine activity that must be carried out by all students at the madrasa. Besides being an Islamic school, this is felt to be able to develop a tradition of developing student faith. The implementation of the fardhu 
prayer in congregation at the madrasa continues in their daily life at home so as to curb the spirit of the students' syahwiya which then creates good morals in their lives. Fardhu dzuhur and Asr prayers are carried out as a madrasa policy that must be carried out by all students and all teachers. According to the deputy head of the madrasa in the field of curriculum, "this activity has been held for a long time, since 2010, the midday and Asr prayers in congregation have been running. It aims to increase devotion to Allah SWT, to form morals for students, both within the madrasa and outside the madrasa."

The implementation of the fardhu prayer in congregation, both dhuhur and Asr, "is carried out under the leadership of the prayer priest, namely the teacher and assisted by capable students. The implementation of Zuhr and Ashr prayers in congregation at the madrasa is attended by students, both male and female. Due to limited space, men are in the mosque while women are in the classroom "(5). The implementation of the fardhu prayer in congregation has rules, as conveyed by a teacher, that "the madrasa policy provides rules in the implementation of fardhu prayers in congregation and imposes sanctions for students who do not perform it. Students who do not follow the dzuhr and ashr prayers in congregation without clear reasons will be punished by reading istighfar on the madrasa page and memorizing 5 short letters "(2). The implementation of the dzuhr and ashr prayers in congregation is closely monitored by the teacher. This supervision is intended so that the implementation of congregational prayers can run in an orderly manner. The aim of fostering the implementation of the fardhu prayer in congregation is "so that students have social attitudes, prosocial intelligence, mutual respect, honesty, and discipline. In addition, it also strengthens their faith and piety so that they are easy to manage, work hard in learning, and have social sensitivity"(8).

Respect for teachers is the main habit applied in madrasas while students are in school. Starting from entering the school environment in the morning until they leave the madrasah it is obligatory for all students to respect the teacher. Respecting the teacher is the main starting point for letting go of their hearts and souls so that students have a sense of humility and are far from being arrogant. Respect for teachers is the beginning for students to respect others, including those who are older than them. Respecting teachers is a major part of them being able to easily and sincerely receive learning materials at madrasah. Attack the teacher argues that: "We make it a habit for the students to greet the teacher when they enter the madrasa environment. In the morning, the teacher stands in line inside the madrasa gate and in front of the teacher's room, students are required to greet the teacher and say hello first. Every time you meet the teacher, you must say hello and greet him well. Students are accustomed to shaking hands because this is related to the teachings of Islam that shaking hands will fall off the sins of the perpetrators while they are in that place. Saying politely in accordance with Islamic teachings when meeting with teachers both at madrassas and outside madrasas. This habit follows the warmth between students and teachers in the learning process" (2).

The habit of respecting teachers is an important part of not only the relationship between teacher and student, but in it contains blessings in studying. A teacher who provides learning material must be respected by students because he teaches knowledge that will be accepted by students. The recipient of knowledge must apply courtesy so that the knowledge received and obtained will get blessings from Allah SWT. "We realize that with the blessing of knowledge that is gained, students will be successful in their future lives, be it in work, faith, family and society. The blessing of knowledge gained by students is the main point so that they can live successfully. So the sincerity of the teacher who provides knowledge and sincerity of students who receive knowledge is something that must be practiced in madrasa life in the learning process" (7). The formation of students' Islamic behavior begins with paying attention to the strength of the soul in humans, namely the power of hammiya or called anger turmoil. Anger flares have the power to always show anger and can greatly affect a person's attitude. Hammiya power can be controlled, as practiced in this madrasa, with dzikrullah and the shiyam sunnah. The use of these two habits is able to control the strength of the hammiya which gives birth to shaja'ah behavior. Syaja'ah's behavior gives birth to good practices, namely jud, hilm, mujahadah, and sabr. 
Most of the teachers in Madrasah Tsanawiyah Negeri 3 realize that the dzikrullah method is able to foster calm in students. The teacher applies the dzikr method by reciting the recitations simultaneously. This method is done twice every day, after dhuha prayer and noon prayer. The teacher recites dzikr and is followed by the students simultaneously. It was led by a teacher and accompanied by two students who had good voices and clear pronunciation. One teacher revealed that: "The practice of dzikrullah habituation is carried out in congregation during dhuha prayer and dzuhur prayer in congregation. All students follow and lead by a teacher who takes turns in leading. The goal is that students have a high mental awareness and are close to Allah so that they have noble morals in life. One of our missions at this madrasa is to develop Islamic values to shape the noble morals of students. Dzikr presents Allah the Almighty with eternal memory wherever and whenever. Dzikr tries to awaken the memory power, remembers Allah's laws, examines the process of natural events, and also means taking lessons and warnings. Basically, dzikr or remembering Allah has a very broad scope, it can even be said of all activities or actions that are carried out with the aim of pleasing Allah's pleasure. Moral development of students with dzikr refraction strategy that is oriented towards heart arrangement. The heart plays an important role in human life because the good and bad of humans are very much dependent on the condition of the heart "(6).

The habit of dhikr after prayer has an impact on students who give rise to a humble attitude, not arrogant, always introspective, has good character. So far it can be seen in the changes in students "there are at least seven characters that emerge from students who have practiced dhikr intensively, namely; ability to solve problems both personal and social problems; high emotional resilience; inner calm; not anxious; self-control, self-control, not getting carried away wherever he goes, especially adolescents who lack self-control; understanding himself well, finding his identity; and a super moral consciousness "(1). The policy at MTs Negeri 3 Kota Pekanbaru requires all students to observe the Sunnah fast on Monday and Thursday. The implementation of this Sunnah fasting aims to manage the mentality of students so that they have a gentle nature, are easy to manage in learning, love learning, believe in themselves, and have good faith. In addition, to develop virtuous behavior so that students avoid controlling anger, shackles of mental ugliness so as to give birth to syaja'ah (courageous) and patient behavior "(8).

Madrasas make a rule that during the day they do not allow lunch and the canteen is closed. In the afternoon the madrasa provides ta'zil to students who want to break their fast at the madrasa. However, students are also given freedom to break their fast at home. This activity is carried out regularly to raise awareness of students as well as to get closer to Allah SWT. One student stated, "At first, I had a hard time keeping up with this routine, but slowly I adapted, and finally I was able to hold back my emotions". A teacher's confession revealed that, "With the application of the shiyam method, students are more manageable, respect the teacher, more patient, and able to control emotions". One teacher revealed: "Carrying out the sunnah fast as recommended by the Messenger of Allah is a practice that is widely practiced by Muslims. Especially by knowing the goodness and advantages that will be obtained from this sunnah fast. If someone practices this sunnah fast, he will find a purpose in life and make things easier, with the blessing that this practice will flow both to the soul and person of a Muslim "(5). Sunnah fasting has various impacts on student behavior in being social (adapting) with people in the madrasa environment. "The social abilities of students who are fasting improve while they are fasting. They have an increased ability to interact well with each other, have a high level of awareness in managing the emotions of themselves and others "(4).

Cultivating the mental strength of mufakkara as a thinking power capable of giving birth to knowledge-loving behavior and fathanah requires familiarization with education. This power is a crucial element because it is able to give birth to a glorious civilization. The strength of mufakkara must be cultivated in life activities with maximum education. Development is carried out by implementing muhadharah activity, and Islamic integrative learning. The goal is to form the behavior of hikmah (wisdom), which then gives birth to the act of loving knowledge and fathanah. Muhadharah is a routine activity carried out once a 
week which is followed by students. "Muhadharah activities are carried out every Friday morning as a training for students to have the skills to analyze and communicate thoughts. This muhadharah activity is intended as a means of providing Islamic da'wah for students in the community later. Muhadharah is one of the activities that is quite effective in training students' character, courage and skills. Dare to speak in front of the crowd (his friends), and is also supervised by several clerics who are assigned to guide this Muhadharah activity"(3). Students who have good muhadharah skills, then become the initial capital for him to enter the community, and as a form of habituation of internalizing moral values in students. "If this courage and abilities are well developed, it is possible that he will become a great orator who can place himself in front of a diverse audience of listeners. Besides accustoming them to have the morals to convey kindness to society"(6). One teacher revealed that:

"At our Madrasah, muhadharah activities are routine activities carried out every Friday, with training programs for moderators, trainers, Friday sermons, and various types of remarks being developed with the consideration of the paradigm in society that requires students to be more responsive and mingle when interacting with individuals. others in the social group. In addition, a student will usually gain the trust of the surrounding community to become a leader / leader in various activities"(2). Muhadhoroh activities in this madrasa, begin with the paradigm "convey it from me even if it is only one verse." Such is the Hadith narrated by Bukhari which motivates Muslims to preach. In practice, the delivery of Islamic teachings in addition to writing must also be oral. Like other methods of da'wah, speech also demands special abilities. A preacher, preacher and orator must master the various techniques and materials he delivers. In addition, mentally also have to be trained and tested to be able and dare to speak in front of a crowd. Even though the material is ripe, it is mastered, without being mentally trained the delivery of the material can be chaotic and far from expectations. Realizing that madrasas are Islamic educational institutions that prepare students to fight and spread Islamic teachings through various methods also do not forget to equip students with speech skills. This muhadharah activity has benefits for the moral development of students in madrasas. One teacher revealed that:

"This muhadharah activity aims to equip students in various aspects; cognitive (intellectual), affective (attitudes and behavior) and psychomotor (skills). Character education is one of the concepts of the affective dimension and is the main target of educational activities in madrasas. Student character development is pursued through various student coaching activities. One form of student activity program is muhadharah (oratory practice) "(8). The development of students' mental powers of mufakkara is carried out by teaching Islamic values in learning at madrasahs carried out intensively. The integrity of Islamic values is applied to all subjects in madrasas. This is done in order to develop students' Islamic mindset so that it gives birth to the character of hikmah (wisdom) and fathanah. Aqidah values are the main part that is integrated by all madrasah teachers in learning activities. To instill the value of the faith, the teacher always links the material taught with the verses of the Qur'an, al-Hadith, and Islamic history. The teacher relates the value of devotion to Allah SWT in every material taught. One teacher revealed, "I relate the learning material that I teach with the Islamic history of mathematics. I do this so that the students will know more about God's power so that their faith will increase and their love for knowledge will strengthen" (6). Here the teacher conveys good and bad grades such as the lecture method, discussion, or assignments. As said by a madrasa teacher that "instilling the value of aqidah in the child apart from using lectures first then I use the assignment method, with the aim of the child being able to know the values of faith itself such as not associating partners with Allah, only worshiping Allah nothing else, which is important. know the basics first "(2). The attitude of faith is always alive and seen in daily activities. Students who have self-confidence, very strong self-abilities, have a wise attitude and have the drive to do good things which are all based and built because of their faith in themselves and have the principle that only in Allah and glorify and maintain God's character.

After going through the value transformation stage, the teacher uses the value transaction stage where in this stage it is not only the teacher as the center but there is feedback from students. In this process the teacher can use the question and answer 
method or discussion, habituation, and exemplary, so that students will want to think and try to respond to what the teacher has explained. This is in line with what the Akidah Akhlak teacher said: "I often use the dialogue method, so that the children want to think again about what I have said. Usually I ask them to discuss one bench or form a group. If to see the children's responses, I ask them sometimes then they answer that too so that they have the courage to present their opinion"(7). The findings of this study are reinforced by research put forward by llyasin (2020) that the mandate of the constitution implies the need to integrate religious values in learning, especially in science. Integration of Islamic values in learning by combining Islamic values to make it coherent. Science and religion applied in the form of material science are integrated with religious material or religious affairs integrated with science material. So with this, Islamic values are very important in every learning process in schools for the formation of believing and pious students.

\section{Discussions}

The findings of this research indicate that the internalization of Islamic values is very appropriate in developing the morals of students in Islamic education. The formation of Islamic behavior of students begins by focusing on the power of the soul in humans, namely the power of syahwiya or commonly called lust. Worldly lust is a soul that always puts forward materialistic desires and worships a hedonistic world without limits. The power of syahwiya must be suppressed in life activities by; habituation of duha sunnah and fardhu prayers in congregation, amd get used to respect the teacher. Both of these methods are able to suppress the soul's power of shahwiya, which in turn give birth to 'iffah' virtuous attitudes and deeds. Strengthening the virtue of 'iffah with these three methods produces jud, syaka', amanah, 'afwu, zuhud, rahmah, and hilm. It is these virtues that make students righteous individuals.

The previous results, illustrate that the implementation of the Duha prayer is carried out by instilling the discipline aspects of students being taught to make good use of time, and remembering Allah SWT (Rosad, 2020; Warasto, 2018). The practice of dhuha prayer is able to develop the morals of students well in everyday life, namely morals in themselves, parents, society, and the environment. Habituation of dhuha prayer has an impact on the emergence of jud, shakha ', qana'ah, rahmah and hilm behavior. Previous findings reinforce this finding that the inculcation of moral values through the habit of praying dhuha is able to realize the foundation of pious and superior children (Amri et al., 2019; Pertiwi \& Anwar, 2020). Dhuha prayer cerrelationally has a significant effect on student morals (Rifa'i \& Sunariya, 2020; Suryapermana \& Syafuri, 2020). The dhuha prayer activity program gave birth to devotional behavior, formed good morals and trained student discipline. The most meaningful dhuha prayer for students 'Islamic morals in the context of human relationships is that students' attitudes towards parents and teachers are more polite, respect time and discipline and respect for each other (Badriyati \& Usman, 2020; S. Tambak \& Sukenti, 2020).

The results of this study with other studies which state that the practice of dhuha prayer on these students creates superior and competitive students who combine intelligence and spirituality (Biantoro, 2019; Nurani, 2019). The habituation of Duha Sunnah prayer in students is very effective and affects the formation of students who are praiseworthy, namely generous, loving others, and honest. Dhuha prayers performed by students have a strong relationship with the students' morals. The world of Islamic education has many goals to be achieved, including in cultivating noble moral behavior in students (Sapitri, 2020; Wati et al., 2019). With the habituation of dhuha prayers at school and outside of school, students should be able to understand and be able to build noble morals in their respective students. The findings of this study are corroborated by the results of research that fostering the implementation of fardhu prayer in congregation aims to make them accustomed to discipline and loving others (Andriane \& Erhamwilda, 2020; S. Tambak et al., 2021). Previous research found that fardhu prayer in congregation affects the spiritual quotient of students in life (Budianto, 2020; Dahlan et al., 2020). The ability of students to develop Islamic behavior in solving life problems can be significantly improved. 
The research findings where respect for teachers has a positive impact on the character of students (Miller et al., 2017). Respect for tacher impacts the character of students in school life and society. Students feel comfortable and feel that adults will do good and protect them in every difficulty they experience. Respect for teachers, the relationship between teachers and students, and the school climate are very important in shaping the character of students in schools. The formation of characters with respect is the main part that teachers must do and familiarize themselves with. Because respect for the teacher is a noble quality that brings glory to students and makes them love their lessons (Balyer, 2019; Liang et al., 2020; Zhou et al., 2020). The formation of students' Islamic behavior begins with paying attention to the strength of the soul in humans, namely the power of hammiya or called anger turmoil. Anger flares have the power to always show anger and can greatly affect a person's attitude. Hammiya power can be controlled, as practiced in this madrasa, with dzikrullah and the shiyam sunnah. The use of these two habits is able to control the strength of the hammiya which gives birth to shaja'ah behavior. Syaja'ah's behavior gives birth to good practices, namely jud, hilm, mujahadah, and sabr.

The practice of dzikrullah is able to make students have a strong influence on their ability to control themselves, thus giving birth to benevolent behavior (Pauzi et al., 2020; Wati et al., 2019). Dzikrullah is a training technique or method used to train attention in order to increase the level of consciousness, which in turn can bring mental processes to a greater control. Dhikr, as an effort to concentrate the mind on a certain object, an effort to release or distance oneself from all the complications and physical and mental disorders or anything that disturbs the mind, and repeats the words or meaning of certain objects. Dzikr is only done by Muslims whose aim is to always remember Allah and reflect on all of His creation so that it is useful for physical and spiritual health which those who meditate cannot feel. Various research results show that the dzikrullah used to pray has a major impact on the morals of students in school life and society. The process of dzikrullah carried out by students has an impact on high learning motivation in life (Kosim et al., 2019; Suryapermana \& Syafuri, 2020; S. Tambak \& Sukenti, 2020). The dzikir is in the form of obeying and obeying all the rules of Allah. Even the meaning of adzkurkum is not only limited to remembering, but Allah will give help, give forgiveness, give guidance, give a high degree. Dzikr is obedience to Allah, whoever is obedient to Allah then he has been doing dzikr and whoever is disobedient is not including those who do dhikr (S. Tambak et al., 2019).

The habit of fasting provides good and positive wisdom for the emotional intelligence of students who routinely practice it. With this sunnah fasting, student behavior grows with behavioral habits including; (1) self-introduction, (2) self-control of emotions, (3) increased self-motivation, (4) development of self-empathy and (5) development of self-social attitudes. The habit of fasting sunnah can develop other virtuous behaviors in students (Samsinar \& Fitriani, 2020). This is because fasting sunnah can suppress the lust of students (Ahmad \& Tambak, 2018; Putra \& Ibrahim, 2020; S. Tambak et al., 2018). This character formation is due to the rules of the circumcision fast itself that can allow children to have an honest and trustworthy character. Cultivating the mental strength of mufakkara as a thinking power capable of giving birth to knowledge-loving behavior and fathanah requires familiarization with education. This power is a crucial element because it is able to give birth to a glorious civilization. The strength of mufakkara must be cultivated in life activities with maximum education. Development is carried out by implementing muhadharah activity, and Islamic integrative learning. The goal is to form the behavior of hikmah (wisdom), which then gives birth to the act of loving knowledge and fathanah. The muhadharah activities are able to develop students' thinking skills while having a good communication process in the community (Manshur, 2020; Noer et al., 2017). The previous research found that students who make speeches are given the freedom to determine the theme to be delivered (Murdan, 2020). The goal is to make students fluent in reading the material in the speech script. The exercises that are carried out by students are by practicing alone and some are practicing with their classmates which have an impact on better thinking skills, analysis, understanding, and rhetoric delivery. Through extracurricular muhadharah activities greatly helped increase student confidence and student courage (Prayogi \& Shobron, 2020). Students who were 
initially afraid, doubtful, weak, became brave, enthusiastic, think positively. Students who at first only dared to speak in the back now dare to make speeches in front of their friends and teachers (Sukenti et al., 2020; S. Tambak et al., 2019).

The research supports the findings of this study that the internalization of Islamic values in learning is carried out by providing learning material that relates to Islamic values that come from Islamic teachings (Ali et al., 2020). This has an impact on the students' paradigm and their more Islamic behavior. Other research reveals that the internalization process is carried out by linking learning material with human kindness behavior, namely morals to God, humans, the environment and parents (Fahyuni et al., 2020; Hamzah et al., 2020; Putra \& Ibrahim, 2020; S. Tambak et al., 2018). Aspects of Islamic religious values that are internalized in learning give birth to behaviors: love for the Qur'an, love knowledge, respect for teachers, parents and neighbors, love fellow humans, do good deeds; honesty, discipline, independence, and responsibility (S. Tambak, Ahmad, et al., 2020; Syahraini Tambak \& Sukenti, 2017). The process of internalizing Islamic religious values affects the attitudes and behavior of students who are obedient to Allah, have good morals to fellow humans and nature, as well as good, intelligent, brave and critical personalities.

\section{Conclusions and Suggestions}

The results of this study found that Islamic values internalized by madrasah teachers in madrasah tsanawiyah by praying duha sunnah and fardhu in congregation, accustoming respect to teachers, able to manage the syahwiya strength of students, thus giving birth to "iffah" behavior which in turn fosters syakha' behavior, jud, qana'ah, amanah, zuhud, rahmah, hilm, and al-afwu. Internalizing Islamic values of dhikrullah, and accustoming shiyam sunnah, able to curb the strength of students 'hammiya, resulting in syaja'ah behavior, 'adalah, ihsan, insyaf, rahmah, and hilm. Other internalization of Islamic values, namely getting used to muhadharah activities, and Islamic integrative learning, are able to educate students' mufakkara strength, thus giving birth to hikmah (wisdom) and fathanah behavior. It can be concluded that the internalization of Islamic values in developing students' actual morals is duha sunnah and fardhu prayer in congregation, get used to respect the teacher, get used to dzikrullah, accustom shiyam sunnah, muhadharah activity, and Islamic integrative learning, to curb the spiritual power of shahwiya, manage power of hammiya, and educating students powers of mufakkara, thus giving birth to the behavior of 'iffah, jud, syakha', qana'ah, amanah, zuhud, rahmah, hilm, al-afwu, syaja'ah, 'adalah, ihsan, insyaf, mujahadah, sabr, hikmah, and fathanah. The results of this study have implications for the theory of "Islamic moral development" which can be applied to all madrasah education in Indonesia and the Islamic world.

\section{References}

Ahmad, M., \& Tambak, S. (2018). Penerapan Metode Diskusi Dalam Meningkatkan Hasil Belajar Murid Pada Pelajaran Fiqh. Al-Hikmah: Jurnal Agama Dan IImu Pengetahuan, 15(1). https://doi.org/10.25299/jaip.2018.vol15(1).1585.

Ahmed, A., Arshad, M. A., Mahmood, A., \& Akhtar, S. (2019). The influence of spiritual values on employee's helping behavior: the moderating role of Islamic work ethic. Journal of Management, Spirituality \& Religion, 16(3). https://doi.org/10.1080/14766086.2019.1572529.

Ali, N., Miftahusyai'an, M., Prasetyo, A. T., \& Muttaqin, M. I. (2020). Developing religious culture through integrative religious practice in Indonesian state islamic university. ElHarakah, 22(1). https://doi.org/10.18860/el.v22i1.8726.

Amri, M., Saharuddin, S., \& Ahmad, L. O. I. (2019). The Implementation of Islamic Education: The Process of Instilling Akhlakul Karimah (Noble Characters) for Madrasah Tsanawiyah Students. Tadris: Jurnal Keguruan Dan IImu Tarbiyah, 4(1). https://doi.org/10.24042/tadris.v4i1.4070. 
Andriane, A., \& Erhamwilda, E. (2020). The Correlation Between the Habit of Carrying Out Jamaah Prayers with the Discipline Attitude of Students. Ta'dib: Jurnal Pendidikan Islam, 9(1). https://doi.org/10.29313/tjpi.v9i1.6207.

Ayu, S. M., \& Junaidah, J. (2018). Pengembangan Akhlak pada Pendidikan Anak Usia Dini. Al-Idarah: Jurnal Kependidikan Islam, 8(2). https://doi.org/10.24042/alidarah.v8i2.3092.

Badriyati, S., \& Usman, N. (2020). The Principal's Policy in Developing Religious Culture. International Symposium on Humanities, Economics and Social Sciences. https://doi.org/10.2991/assehr.k.200529.061.

Baker, E. R., D'Esterre, A. P., \& Weaver, J. P. (2021). Executive function and Theory of Mind in explaining young children's moral reasoning: A Test of the Hierarchical Competing $\begin{array}{llll}\text { Systems Model. Cognitive } & \end{array}$ https://doi.org/10.1016/j.cogdev.2021.101035.

Balyer, A. (2019). Educational leaders and teacher leaders' roles in humanizing education. Elementary Education Online, 18(3). https://doi.org/10.17051/ilkonline.2019.611500.

Basuki, D. D., \& Febriansyah, H. (2020). Pembentukan Karakter Islami melalui Pengembangan Mata Pelajaran Akidah Akhlak di Madrasah Aliyah An-Najah Bekasi. Jurnal Intelektual: Jurnal Pendidikan Dan Studi Keislaman, 10(2).

Biantoro, O. (2019). Urgency of Islamic Religious Education Teachers in Character Building for Students in Junior High Schools. Al-Hayat: Journal of Islamic Education, 3(2). https://doi.org/10.35723/ajie.v3i2.83.

Budianto, A. (2020). Implementasi Shalat Dhuhur Berjamaah untuk Membentuk Akhlak Siswa di Madrasah Aliyah Negeri 2 Pamekasan. Rabbani: Jurnal Pendidikan Agama Islam, 1(1). https://doi.org/10.19105/rjpai.v1i1.3004.

Dahlan, M., Sirajuddin, M., Miinuddin, A. S., Safi'i, A. N., \& Lovita, A. (2020). Consistency of Rural Muslim Communities in Maintaining Safety (Hifdz Al-Nafs) in Performing the Worship of Daily Prayers (Shalat) in the Midst of Covid-19 Outbreak. Journal of Talent Development and Excellence, 12(1).

Darnell, C., Gulliford, L., Kristjánsson, K., \& Paris, P. (2019). Phronesis and the knowledgeaction gap in moral psychology and moral education: A new synthesis? Human Development, 62(3). https://doi.org/10.1159/000496136.

Fahyuni, E. F., Wasis, W., Bandono, A., \& Arifin, M. B. U. B. (2020). Integrating Islamic values and science for millennial students' learning on using seamless mobile media. Jurnal Pendidikan IPA Indonesia, 9(2). https://doi.org/10.15294/jpii.v9i2.23209.

Ganjvar, M. (2019). Islamic Model of Children's Spiritual Education (CSE); its influence on improvement of communicational behaviour with non-coreligionists. International Journal of Children's Spirituality, https://doi.org/10.1080/1364436X.2019.1624254.

Garrigan, B., Adlam, A. L., \& Langdon, P. E. (2018). Moral decision-making and moral development: Toward an integrative framework. Developmental Review, 49. https://doi.org/10.1016/j.dr.2018.06.001.

Hamzah, D., Tambak, S., \& Tanjung, W. U. (2020). Overcoming self-confidence of Islamic religious education students: The influence of personal learning model. Journal of $\begin{array}{llll}\text { Education and Learning (EduLearn), } & \text { 14(4). }\end{array}$ https://doi.org/10.11591/edulearn.v14i4.16759.

lannuccilli, M., Dunfield, K. A., \& Byers-Heinlein, K. (2021). Bilingual children judge moral, social, and language violations as less transgressive than monolingual children. Journal of Experimental Child 208. https://doi.org/10.1016/j.jecp.2021.105130.

Ibam, E., Adekunle, T., \& Agbonifo, O. (2018). A Moral Education Learning System based on the Snakes and Ladders Game. EAI Endorsed Transactions on E-Learning, 5(17), 19. https://doi.org/10.4108/eai.25-9-2018.155641.

Jia, F., Krettenauer, T., \& Li, L. (2019). Moral identity in cultural context: Differences between Canadian and Chinese university students. Journal of Moral Education, 48(2). https://doi.org/10.1080/03057240.2018.1499504. 
Khaironi, M. (2017). Pendidikan Moral Pada Anak Usia Dini. Jurnal Golden Age, 1(01), 1. https://doi.org/10.29408/goldenage.v1i01.479.

Kosim, M., Kustati, M., Sabri, A., \& Mustaqim, M. (2019). Strengthening Students' Character through Tahfidz Quran in Islamic Education Curriculum. Jurnal Pendidikan Islam, 8(1). https://doi.org/10.14421/jpi.2019.81.69-94.

Laeheem, K. (2020). Causal relationships between religion factors influencing ethical behavior among youth in the three southern border provinces of Thailand. Children and Youth Services Review, 108. https://doi.org/10.1016/j.childyouth.2019.104641.

Liang, C. T., Rocchino, G. H., Gutekunst, M. H., Paulvin, C., Melo Li, K., \& Elam-Snowden, T. (2020). Perspectives of respect, teacher-student relationships, and school climate among boys of color: A multifocus group study. Psychology of Men \& Masculinities, 21(3). https://doi.org/10.1037/men0000239.

Luttrell, A., Philipp-Muller, A., \& Petty, R. E. (2019). Challenging moral attitudes with moral messages. Psychological Science, 30(8). https://doi.org/10.1177/0956797619854706.

Manshur, F. (2020). Typical Literary Works of Pesantren on Righteousness Teaching within Cultural Transformation. Journal of Social Studies Education Research, 11(4).

Maulida, A. (2017). Konsep dan Desain Pendidikan Akhlak dalam Islamisasi Pribadi dan Masyarakat. Edukasi Islami: Jurnal Pendidikan Islam, 2(4). https://doi.org/10.30868/ei.v2i04.36.

McGrath, C., Palmgren, P. J., \& Liljedahl, M. (2019). Twelve tips for conducting qualitative research interviews. Medical Teacher, 49(1). https://doi.org/10.1080/0142159X.2018.1497149.

Miller, A. D., Ramirez, E. M., \& Murdock, T. B. (2017). The influence of teachers' self-efficacy on perceptions: Perceived teacher competence and respect and student effort and achievement. Teaching and Teacher Education, 64. https://doi.org/10.1016/j.tate.2017.02.008.

Mu'awanah, E. (2018). Psychology Counseling of Sufistic Method for an EX-Hoodlum and Prostitute to Be Islamic Behaviour Shift (Quran Memorizers). Psychology Research, 8(3). https://doi.org/10.17265/2159-5542/2018.11.003.

Murdan, M. (2020). Pesantren's Traditions in Preparing Human Resources (Santri) at Ibnul Amin Pamangkih and Rasyidiyah Khalidiyah Amuntai Pesantren. Ta'dib: Jurnal Pendidikan Islam, 25(2). https://doi.org/10.19109/tjie.v25i2.6738.

Netolicky, D. M., \& Barnes, N. (2018). Method as a journey: a narrative dialogic partnership illuminating decision-making in qualitative educational research. International Journal of Research \& Method in Education, 41(5). https://doi.org/10.1080/1743727X.2017.1295938.

Noer, A., Tambak, S., \& Rahman, H. (2017). Upaya Ekstrakurikuler Kerohanian Islam (ROHIS) dalam Meningkatkan Sikap Keberagamaan Siswa di SMK Ibnu Taimiyah Pekanbaru. Jurnal Pendidikan Agama Islam Al-Thariqah, 2(1). https://doi.org/10.25299/althariqah.2017.vol2(1).645.

Nurani, N. (2019). Implementasi Pembentukan Akhlak Terpuji Melalui Pembiasaan Shalat Dhuha pada Kelompok B Usia 5-6 Tahun TK Islam An Nuur Tahun Ajaran 20182019. Jurnal Kependidikan, 5(2). https://doi.org/10.37150/jut.v5i2.488.

Pauzi, A. P., Addieningrum, F. M., Aslina, N., \& Maskur, S. (2020). The Relationship Between Remembering God (Dhikr) and Stress Prevention of Life Problem. PalArch's Journal of Archaeology of Egypt/Egyptology, 17(7).

Pertiwi, I., \& Anwar, S. (2020). Character Education at Sekolah Alam Minangkabau and Sekolah Alam Ar-Royyan Padang. International Journal of Educational Dynamics, 2(2). https://doi.org/10.24036/ijeds.v2i2.267.

Prayogi, R. D., \& Shobron, S. (2020). Arabic as Second Language of Educated Generation. Ittishal Educational Research Journal, 1(1). https://doi.org/10.51425/ierj.v1i1.2.

Putra, A. P., \& Ibrahim, M. (2020). Are There Levels of Students Morales? The Effects of Biological Problem Solving on Moral Development. International Education Studies, 13(6). https://doi.org/10.5539/ies.v13n6p32. 
R. Burke Johnson, L. C. (2014). Educational Research Quantitative, Qualitative, and Mixed Approaches. In SAGE Publications India Pvt. Ltd (5th ed., Vol. 4, Issue 1). Library of Congress Cataloging-in-Publication Data. https://doi.org/10.4324/9781351004626-12.

Rifa'i, M., \& Sunariya, E. (2020). Life Skill Education Through Extracurricular Religion In The Tunadagsa Children In SLBN Gending. International Journal of Education, Information Technology, and Others, 3(2). https://doi.org/10.5281/zenodo.3991379.

Rosad, W. S. (2020). Pelaksanaan Shalat Dhuha dalam Meningkatkan Kecerdasan Spiritual Siswa Kelas 3 Madrasah Ibtidaiyah Ma'arif NU Ajibarang Wetan. Al-Munqidz: Jurnal Kajian Keislaman, 8(1). https://doi.org/10.52802/amk.v8i1.195.

Ru'iya, S. (2019). A Review of Research on Bullying Behavior in Indonesian Islamic Education Institutions: Analysis of Ecological Theory. In 2019 Ahmad Dahlan International Conference Series on Education \& Learning. Social Science \& Humanities. https://doi.org/10.2991/adics-elssh-19.2019.14.

Safitri, N., Kuswanto, C. W., \& Alamsyah. (2019). Metode Penanaman Nilai-Nilai dan Moral Agama Anak Usia Dini. Journal of Early Childhood Education, 1(2), 29-44. https://doi.org/10.15408/jece.v1i2.13312.

Salistina, D. (2015). Pendidikan Anti Korupsi melalui Hidden Curriculum dan Pendidikan Moral. Ta'allum: Jurnal Pendidikan Islam, 3(2). https://doi.org/10.21274/taalum.2015.3.2.163-184.

Samsinar, S., \& Fitriani, F. (2020). Character-Based Learning and Self-Development to Improve the Students' Character Education. Lentera Pendidikan: Jurnal IImu Tarbiyah Dan Keguruan, 23(1). https://doi.org/10.24252/lp.2020v23n1i10.

Sapitri, I. S. (2020). Hubungan Pembiasaan Shalat Dhuha Dengan Akhlak Siswa Sekolah Menengah Atas. Jurnal Pendidikan Islam Indonesia, 5(1). https://doi.org/10.35316/jpii.v5i1.246.

Setiawati, E., Desri, M., \& Solihatulmilah, E. (2019). Permainan Ular Tangga Dalam Mengingkatkan Kemampuan Moral Anak. JURNAL PETIK. https://doi.org/10.31980/jpetik.v5i1.494.

Sukenti, D., Tambak, S., \& Charlina. (2020). Developing Indonesian language learning assessments: Strengthening the personal competence and Islamic psychosocial of teachers. International Journal of Evaluation and Research in Education, 9(4). https://doi.org/10.11591/ijere.v9i4.20677.

Suryapermana, N., \& Syafuri, B. (2020). Tahajud Prayer and Dhikr after Fardhu Prayer to Improve Santri's Spiritual Intelligence. International Conference on Community Development. https://doi.org/10.2991/assehr.k.201017.158.

Tambak, S., Ahmad, M., Sukenti, D., \& Ghani, A. R. B. A. (2020). Profesionalisme Guru Madrasah: Internalisasi Nilai Islam dalam Mengembangkan Akhlak Aktual Siswa. Jurnal Pendidikan Agama Islam Al-Thariqah, 5(2). https://doi.org/https://doi.org/10.25299/al-thariqah.2020.

Tambak, S., Ahmad, M. Y., \& Sukenti, D. (2019). Strengthening Emotional Intelligence in Developing the Madrasah Teachers' Professionalism. Akademika: Journal of Southeast Asia Social Sciences and Humanities, 90(2). https://doi.org/10.17576/akad-2020-9002-03.

Tambak, S., Amril, A., \& Sukenti, D. (2021). Islamic Teacher Development: Constructing Islamic Professional Teachers Based on The Khalifah Concept. Nazhruna: Jurnal Pendidikan Islam, 4(1). https://doi.org/10.31538/nzh.v4i1.1055.

Tambak, S., Amril, M., Khairi, Z., \& Sukenti, D. (2018). Development of Madrasah Teacher Professionalism by Strengthening the Khalifah Concept and Islamic Psychosocial Perspective. International Conference on Islamic Education (ICIE 2018). https://doi.org/10.2991/icie-18.2018.7.

Tambak, S., Humairoh, S., Noer, M. A., \& Ahmad, M. (2020). Internalization of Riau Malay Culture in Developing the Morals of Madrasah Ibtidaiyah Students. Al Ibtida: Jurnal Pendidikan Guru MI, 7(1). https://doi.org/10.24235/al.ibtida.snj.v7i1.5954. 
Tambak, S., \& Sukenti, D. (2020). Strengthening Islamic Behavior and Islamic Psychosocial in Developing Professional Madrasah Teachers. Cakrawala Pendidikan: Jurnal IImiah Pendidikan, 39(1). https://doi.org/10.21831/cp.v39i1.26001.

Tambak, Syahraini, \& Sukenti, D. (2017). Implementasi Budaya Melayu dalam Kurikulum Pendidikan Madrasah Ibtidaiyah di Riau. MIQOT Jurnal IImu-IImu Keislaman, 41(2). https://doi.org/10.30821/miqot.v41i2.409.

Thambu, N., Naidu, N. B. M., \& Sukadari. (2021). Developing Higher Order Thinking Skills through Blended Learning among Moral Education Students. Turkish Journal of Computer and Mathematics Education, 12(3), 808-819. https://doi.org/10.17762/turcomat.v12i3.788.

Tomasello, M. (2018). The normative turn in early moral development. Human Development, 61(4). https://doi.org/10.1159/000492802.

Warasto, H. N. (2018). Pembentukan Akhlak Siswa. Jurnal Mandiri: Ilmu Pengetahuan, Seni, Dan Teknologi, 2(1). https://doi.org/10.33753/mandiri.v2i1.32.

Wati, Sumarwati, \& Saddhono. (2019). Islamic religious values in dhukutan traditional ceremony as character education for elementary school students. El Harakah, 21(1). https://doi.org/10.18860/el.v21i1.5615.

Yusoff, Hisyam, M., Azra, A., \& Fatimah. (2021). Metacognitives And Morals: The Qur ' an As A Guide Research Article Metacognitives And Morals: The Qur' an As A Guide. Turkish Journal of Computer and Mathematics Education, 12(4), 659-664. https://doi.org/10.17762/turcomat.v12i4.550.

Zainuddin, Z. (2019). Pengembangan Buku Ajar Akidah Akhlak untuk Meningkatkan Pemahaman Siswa Madrasah. Jurnal Pendidikan Islam Indonesia, 3(2). https://doi.org/10.35316/jpii.v3i2.141.

Zhou, J., Dawson, P., Tai, J. H. M., \& Bearman, M. (2020). How conceptualising respect can inform feedback pedagogies. Assessment \& Evaluation in Higher Education. https://doi.org/10.1080/02602938.2020.1733490. 